\title{
Review of Wesley J. Smith's A Rat is a Pig is a Dog is a Boy: The Human Cost of the Animal Rights Movement
}

\author{
Angus Taylor \\ Department of Philosophy \\ University of Victoria \\ amt@uvic.ca
}

\section{Book Review}

Ingrid Newkirk's notorious assertion that "a rat is a pig is a dog is a boy" provides the title for Wesley J. Smith's book decrying the animal-liberation movement and propounding the doctrine of human exceptionalism. More than simply a claim about the superior mental powers of Homo sapiens, human exceptionalism holds that humans possess a unique moral worth that endows them alone, among all living creatures, with the right never to be treated merely as means to the ends of others. The idea that humans have this exceptional moral status is hardly new, but the fact that it has now become an "ism" reflects the current struggle over where to draw the boundaries of the moral community.

In speeches, in newspaper columns, on his blog, and now in A Rat Is a Pig Is a Dog Is a Boy: The Human Cost of the Animal Rights Movement, Smith argues that those who reject human exceptionalism, including proponents of animal liberation and many bioethicists and proponents of biotechnology, open the door to the elimination of human rights. "After all," he says, "if we ever came to consider ourselves as just another animal in the forest, that would be precisely how we would act” (2007, p. 14).

In other words, either we are unique in having significant moral standing, or we are merely exploitable objects, like other creatures. This dichotomy runs throughout Smith's thinking. Not surprisingly, then, the conclusion is that if humans are treated like animals, they will be treated unacceptably. Smith repeatedly expresses amazement 
and outrage that proponents of animal liberation would want to "degrade" humans to the level of mere animals and concludes that these "extremists" are misanthropes with an anti-human agenda. His concern has led him to appear before the U.S. House of Representatives Judiciary Subcommittee on Crime, Terrorism, and Homeland Security to advocate strengthening the law against animalrights "terrorism."

Smith's book is a polemic aimed at the general public. He paints animal liberation with broad, dark brush strokes. He devotes much space to describing violent acts of groups like the Animal Liberation Front, and sees this "terrorism" as a characteristic part of the movement as a whole. While acknowledging that Gary Francione and a few others reject violence, Smith (2009, p. 137) says, "terrorism in the name of animal rights can be thought of as one arm of an octopus, with PETA, HSUS, philosophers, financiers, and the like being other tentacles.”

Smith demonstrates little familiarity with the large range of literature on the moral status of animals, and indeed shows little interest in making a philosophically rigorous argument. Nonetheless, I think a fair summation of his position would go something like this:

The possession of moral agency confers moral rights and responsibilities upon human beings. Animals, who universally lack moral agency, can have neither rights nor responsibilities. Only moral beings have the fundamental right never to be used as mere means for the ends of others. Those humans who are not themselves moral agents have the same right to protection as moral agents because (1) they share the essential property of being moral by nature, and (2) to treat them differently would undermine the distinction between humans and animals and thus would undermine both the concept of universal human rights and the legitimate right of humans to exploit non-humans in ways they consider appropriate.

Although he says his doctrine of human exceptionalism is not predicated on a rejection of evolution or on a belief in God, Smith is a prominent member of the Discovery Institute, the Seattle-based 
organization dedicated to promoting "representative government, the free market, and individual liberty" and that is at the forefront of the campaign to get Intelligent Design accepted as a legitimate scientific theory. David Klinghoffer (2010), a Senior Fellow at the Discovery Institute, clearly believes that Intelligent Design and Smith's stance on animal liberation are cut from the same exceptionalist cloth and that Smith's book is a salvo in the struggle against the moral depravity of Darwinism, which allegedly reduces humans to the status of mere animals. Smith's blog, Secondhand Smoke, is hosted by The Institute on Religion and Public Life, whose aim is "to advance a religiously informed public philosophy for the ordering of society." Smith is also a climate-change sceptic who associates globalwarming "hysteria" with worship of nature at the expense of human well-being.

Smith is firmly opposed to what he calls "personhood theory," that is, to making membership in the moral community dependent on an individual's possessing some specified level of cognitive capacity. To go down that road, he maintains, is to reject the notion of fundamental moral equality among humans that is crucial to a humane and civilized society. But when it comes to the distinction between humans and animals, Smith is eager to conflate having exceptional cognitive abilities with having exceptional moral value. He thinks the very fact that humans can advocate moral rights for animals (something animals cannot understand) shows that humans are exceptional and therefore proves that only humans are entitled to moral rights. With this in mind, he often chides liberationists for not understanding that they contradict themselves simply by advocating animal liberation.

Smith's case for human exceptionalism rests on the claim that all humans have a nature characterized by moral agency. He is not fazed by the fact that not all humans are moral agents, insisting that we focus instead on the "intrinsic nature" of the species. He apparently believes that each species has an essence, a defining trait or set of traits that is shared by every one of its members - in contrast to the 
evolutionary understanding of species as changing populations of individuals that are closely related genetically, but not essentially identical. (The notion of species essentialism is commonly associated with pre-Darwinian biological thought, but John Wilkins (2009) argues that even before Darwin essentialism, in the sense noted, was not prominent.)

How individual humans who show no sign of actual or even potential moral agency can share in the hypothesized moral essence of the species is something Smith never makes clear. According to Margaret Somerville (2010), a bioethicist he admires, human exceptionalism rests on the fact that "we humans have a "human spirit,' a metaphysical, although not necessarily supernatural, element as part of the essence of our humanness." This is a fancy way of saying nothing: humans are special because they have some mysterious quality that makes them special. As an explanation, it recalls the physician in a Molière play who attributed the sleepinducing effects of opium to its dormitive potency. At least the physician was pointing to an empirically verifiable property.

If the concept of every human's having a special moral value deriving from "the essence of our humanness" is unpersuasive, what about the related "argument from species normality" - the distribution of special value to all humans on the basis of the moral agency of most humans? Smith invokes Carl Cohen's highly dubious assertion that moral status is to be assigned on the basis of kind rather than on the basis of individual attributes. So, since human beings who are not moral agents are members of a class, or kind, of being that typically does display moral agency, they are entitled to the unique respect that moral beings deserve. Smith offers no reason for us to assent to this kind of claim (claim of kind) and he ignores, or is unaware of, the logical problems it raises - instead warning readers against the "clever sophistry" of philosophers who judge moral status on the basis of individual capacities.

As Nathan Nobis (2004) has pointed out, basing the treatment of individuals on the typical attributes of members of the class(es) to 
which they belong opens the door to absurdities such as giving passing grades to students who have failed their exams. (Perhaps Cohen ought to deny rights to humans, who are sentient beings, on the basis that most sentient beings lack moral capacities?) Then there is the error of attributing to a class what can only belong to some of its individual members. A species is not an experiencing subject. It has no beliefs or desires. It is not a conscious being and so cannot possess moral agency. If a species, as such, has some kind of value, that value derives not from possessing moral agency but from, say, its place in the web of life, or perhaps from the fact that its continued existence supports the existence of individuals who are moral agents. A human lacking moral agency cannot derive intrinsic value of the kind conferred by having moral agency simply and merely from membership in the human species.

This is not to say that species membership is never relevant. A chimpanzee or a parrot may have the same facility for language acquisition as a mentally handicapped human. But it does not follow that the animal should be accorded the same right to be taught a language, since the animal does not characteristically have the same interest in participating in human society (Anderson 2004). It is not unreasonable, then, to hold that humans, including the mentally handicapped, will have certain species-specific rights that animals do not have. In addition, acquired duties, such as those we have to family and friends by virtue of our lived relationships with them, can sometimes give us reason to favour one individual over another.

None of this provides justification for treating any sentient being as mere means to our ends. Even if can be shown (on some account more plausible than Cohen's) that all human beings deserve an elevated moral status, it is not clear why this elevated status should entail the right to exploit, kill, and consume beings of lesser status especially in those instances where no human vital needs are at stake. The issue of moral agency is a red herring. There is no logical requirement that all humans be moral "by nature" in order for every one of them to be entitled to respectful treatment. If not Tom Regan's 
"subject of a life" theory, then surely Gary Francione's sentiencebased rights view would give Smith all he desires in terms of recognizing the equal inherent worth of all humans, including the mentally handicapped. By recognizing sentience as a sufficient condition for the right to be treated with respect, Smith could make a rationally defensible argument against the abuses to which he believes many incapacitated humans are vulnerable. But his doctrine of human exceptionalism cannot countenance just any ethical view that protects humans, for it is not enough to include all humans within the moral community - one must simultaneously exclude all non-humans. And this is crucial: human exceptionalism is at least as much about whom we are determined to exclude from the moral community as about whom we wish to include within it.

When animals are resources by their very nature, killing and consuming them is hardly an issue. For Smith, the fact that humans are omnivores with a long history of eating meat is enough to remove any fundamental ethical question on this score. Eating meat is natural and nourishing, and that makes it okay. Even "humane meat" must take a back seat to providing the masses with lots of cheap animal flesh. In any case, according to Smith, the alleged horrors of "factory farms" are greatly exaggerated. His "gotcha" response to the claim that "meat is murder" is his "veganism is murder" reductio. Even plant agriculture involves the death of animals via ploughing, harvesting, habitat destruction, etc. So even a diet free of animal ingredients involves the killing of animals, and hence vegans, by their own ethics, must be immoral killers. Smith cites an essay by Steven Davis (2003) that favours an omnivorous diet including grass-fed animals as the best way to minimize deaths, but he neglects to mention critiques that seriously challenge Davis's figures (Lamey 2007; Matheny 2003). Perhaps the omission is understandable: Smith goes on to say that none of this really matters anyway, since we have no moral duty to reduce the number of animals we kill. Abstain from meat or dairy if you wish (Smith suggests this is in itself a harmless, monk-like form of asceticism) but don't claim that one choice of diet is ethically any better than any other. 
When it comes to medical research, Smith has little patience with those who assert that animal experimentation is always unnecessary to advance scientific knowledge and is commonly misleading. He has a point. Though there are reasons to dispute some claims touting the benefits of animal experimentation, animal advocates do their cause no good when they dogmatically insist on the uselessness of such research. For his part, Smith can see nothing inherently troubling about vivisection (in the sense of research that results in harm to animals). Humans, after all, are the only beings with the right never to be treated as mere means.

A different perspective might argue that at least some biomedical experimentation involves a tragic conflict between the vital needs of humans and those of animals. Human stewardship of the natural environment can also sometimes confront us with tragic conflicts between promoting the flourishing of ecosystems and respecting the well-being of individual animals. In this light the world is, unfortunately, not inherently arranged so that problems are always guaranteed to have tidy solutions with no evil consequences. By contrast, Smith's world is a comfortably simple one, in which such tragic conflicts do not exist, because animals are merely resources.

It is surely a sad commentary on civilization in the twenty-first century that we have only begun to debate whether torturing and killing our nearest relatives is acceptable. Passage of legislation granting great apes rights to life, liberty, and freedom from torture would hold out some hope (though no certainty) that they might be saved from extinction and enabled to live relatively free lives, and it would mark significant change in ethical thinking by removing some non-humans from the legal category of property and recognizing their intrinsic moral worth. It is this last bit - recognizing the intrinsic moral worth of members of other species - that is generating fear and loathing among human apes. Although chimpanzees have cognitive faculties roughly equivalent to those of normal three-year-old human children (and according to one study are better than university students at remembering sequences of 
numbers on a screen), there is fierce resistance from Wesley J. Smith and company to granting them the right not to be tortured, killed, eaten, orphaned, kept in tiny cages, deliberately infected with fatal diseases, or to have their body parts used for trinkets or medicines. Some animal advocates object to the campaign for legal rights for apes because it arguably reinforces a hierarchy of dominance in which moral worth is measured in terms of likeness to humans. But Smith believes - correctly, in my opinion - that granting rights to apes would be what has been called "the point of the spear" for breaking the barrier between humans and non-humans.

Smith insists that, rather than ascribing rights to animals, we should recognize that we have a duty to treat them humanely. (He calls himself an advocate of "animal welfare.") In fact, numerous advocates of animal liberation, from utilitarians to feminists to ecosocialists to postmodernists, are sceptical of ascribing rights to animals. And, in any case, the language of animal rights can be translated into the language of strong human duties. But the convenient notion that we have a duty to be "humane" can excuse a multitude of sins. "Humane" is a flexible concept and just about anything can qualify if "humane" is always to be measured by reference to human benefit. By contrast, the inconvenient idea that animals have rights makes excuses more difficult. And that - not philosophical disputation about whether it makes sense to ascribe rights to those who are not moral agents - is the point for Smith: the ascription of rights to animals presents an inconvenient barrier to their being exploited for human gain.

Smith repeatedly expresses the fear that by ascribing rights to animals we will come to see ourselves as no better than they are and will thence behave in brutal ways toward each other. Does he feel he would lose control of his own atavistic anti-social instincts if rights were ascribed to animals - that it is only his knowledge that animals can be exploited and killed for human gain that keeps him on the path of moral probity? Why the grim determination to exclude animals from the moral community? 
Perversely, a sense of human worth can be bound up with such exclusion. It is instructive to note the frequency with which it is asserted that ascribing rights to animals is unacceptable because it would reduce human beings to a brutish, dog-eat-dog level and in effect mean the end of human rights. For Kenan Malik, who believes that animals are Cartesian "zombies" lacking consciousness, human exceptionalism is about transcending the dictates of nature, and to reduce humans to just natural beings is to undermine moral progress. "To put it crudely, viewing beasts as more human is but the other side of viewing humans as more beastly" (2000, p. 232).

This claim makes no sense unless one has decided from the start that animals are unworthy of respect - that they are merely zombies, or (to use a phrase of Smith's) "meat on the hoof." Otherwise, showing respect for animals (or women, or non-white people, or whomever) does not require or imply showing less respect for humans (or men, or white people, or whomever). But those entrenched in the belief that non-humans have merely instrumental value (not to mention those who believe animals are Cartesian machines) find it well nigh impossible to imagine that the inclusion of non-humans within the circle of equal consideration signifies anything other than the loss of human dignity. (There goes the neighbourhood!)

The problem goes beyond this. The fear that we may become "just another animal in the forest" reflects not only the (unsubstantiated) fear that we would lose respect for each other, but existential fear. At a primal level, the subordination and exploitation of the other may appear to be the only guarantee we have of our exceptional status. Hence, it is only by asserting our right to dominate and exploit other sentient creatures that we can overcome the fear that we will share their ultimate fate. It is only in this way that we can overcome the fear of being treated as if we were animals: that is, of being treated the way we treat others who are not human. So we must continue to treat animals like animals to prove to ourselves that we are not just animals who will be treated like 
animals. The irony is that in doing so we may undermine respect for other humans: as Kelly Oliver (2009, pp. 303-04) argues, "The man/animal binary is not just any opposition; it is the one used most often to justify violence, not only man's violence to animals, but also man's violence to other people deemed to be like animals."

The real fear for many is that if our destiny is one with the other living creatures of this world, then we have been abandoned by God and Fate and there is no eternal salvation for us - for surely God cares little or nothing for individual animal lives, from all the evidence around us, including our own treatment of those lives. Yet, it is not only those who wish fervently that an Intelligent Designer has a special plan for them who can feel threatened by the idea that humans and non-humans are in the same boat, morally speaking. So can those who see evolution as certifying human moral superiority ("We've clawed our way to the top of the heap"). The desire to be assured that humans occupy a special place in the universe runs deep, and is not limited to religious believers. Conversely, as Rod Preece makes clear in his important study Brute Souls, Happy Beasts, and Evolution, those who have defended animals on the basis of their kinship with humans have often, at least in the past, been motivated less by the idea of biological evolution than by a religious, and specifically a Christian, belief in the unity of God's creation. This was especially true of the nineteenth-century debate in Britain over vivisection.

Ostensible devotion to science can mask an arrogant dismissal of the non-human world and those who would speak for it. The proscience coterie around the on-line U.K. magazine spiked explicitly defend human exceptionalism and pour scorn on environmentalists and advocates of animal liberation. This rather odd, but hardly obscure, group has morphed over time from left-wing to vociferously pro-free-market. What seems to have remained constant is their ideology of technological triumphalism. This distinguishes them from Wesley J. Smith, who is deeply concerned about the possible misuses of genetic engineering and who decries the transhumanism 
movement, which advocates the use of technology to enhance human minds and bodies in radical ways.

The spiked crowd, Smith, and others notwithstanding, scientific findings and philosophical debate are rendering human exceptionalism increasingly untenable intellectually. No longer is it possible to mount a convincing case that some morally relevant essence or intrinsic capacity distinguishes all humans from all nonhumans. As a more plausible alternative there has emerged what I call "the new argument from nature," which blurs the line between human and non-human and appeals to ecological processes of predation and natural selection (Taylor 2008). This renewed version of human superiority sees us as top predators, defending our own in the struggle for existence. According to the new story, it is not what sets us apart from other animals, but what we have in common with them, that entitles us to exploit them for our gain. In this respect, Smith is fighting yesterday's battle, while the main philosophical contest has already moved over the hill to another field. That said, the doctrine of human exceptionalism is still alive and kicking in the propaganda war of the public arena.

The determination of Smith and company to deny significant moral standing to all non-humans is no way to safeguard human rights. As Tom Regan (1985, p. 24) puts it, "the animal rights movement is a part of, not antagonistic to, the human rights movement. The theory that rationally grounds the rights of animals also grounds the rights of humans." I suggest that the refusal (rather than simple failure) to understand this is to be explained by a pathology of desire for domination over the other, a desire rooted in existential dread. Apart, then, from the propaganda value of tarring the animal-liberation movement with the "terrorist" label, the widespread invocation of the notion of terror by Smith and opponents of "animal rights" reveals a more profound unease. This is the real terror of animal rights: the existential terror induced in those who feel a threat to their privileged place in the grand scheme of things. For Smith, as for Louis XV, it’s “Après moi, le déluge." 
Darwin argued that morality is not something pulled out of thin air by the power of human reason. Even members of social nonhuman species exhibit proto-moral behaviour. The moral sentiment, to sympathize with one's fellows and come to their aid, is naturally selected for because it promotes survival. We are moral because we are natural beings, not because we transcend nature. Today human survival and flourishing require the evolution of our understanding of the moral community. In disconnecting humans from the rest of nature and locating all ultimate value in them, the doctrine of human exceptionalism expresses an objectively outmoded world-view, one that props up what has become a profoundly dysfunctional industrial civilization. Human exceptionalism is not a statement of fact, but an assertion of domination. It exalts one species at the expense of reducing the rest of nature to brute matter, grist for the mill of capital accumulation. Neither human society nor the ecosystems that form its life-support can afford this way of thinking much longer.

At the core of Smith's view is his belief that human dignity is inseparably bound up with domination of the non-human world. Surely there is something very odd about the argument that because we are uniquely moral beings we have the right to harm other creatures even where no vital interest of ours is at stake, and that any attempt to restrict that right is an attack on our dignity. Philosopher Jean Kazez has described this thinking as "wondrously twisted." No doubt, however, many who read Smith's book will find nothing amiss, and indeed will find him to be speaking refreshing common sense. What we have here are different paradigms - incompatible understandings of reality - and there is no common language to bridge the gap. In particular, it seems to me that the case for an ethics of liberation can be understood only to the extent that compassion, or sympathy, or the heart - what Wesley J. Smith constantly denigrates in animal advocates as mere emotion - first makes its audience receptive. 


\section{References}

Anderson, Elizabeth. 2004. Animal rights and the values of nonhuman life. In Animal rights: Current debates and new directions, eds. Cass R. Sunstein and Martha C. Nussbaum. New York: Oxford University Press.

Davis, Steven L. 2003. The least harm principle may require that humans consume a diet containing large herbivores, not a vegan diet. J ournal of Agricultural and Environmental Ethics 16: $387-94$.

Klinghoffer, David. 2010. Reading Wesley Smith: Why the Darwin debate matters. Discovery Institute: Evolution News \& Views (March 15, 2010), http://www.evolutionnews.org/2010/o3/ reading_wesley_smith_why_the_d.html.

Lamey, Andy. 2007. Food fight! Davis versus Regan on the ethics of eating beef. J ournal of Social Philosophy 38: 331-48.

Malik, Kenan. 200o. Man, beast and zombie: What science can and cannot tell us about human nature. London: Weidenfeld \& Nicolson.

Matheny, Gaverick. 2003. Least harm: A defense of vegetarianism from Steven Davis's omnivorous proposal. J ournal of Agricultural and Environmental Ethics 16: 505-11.

Nobis, Nathan. 2004. Carl Cohen's 'kind' argument for animal rights and against human rights. J ournal of Applied Philosophy 21: 43-59.

Oliver, Kelly. 2009. Animal lessons: How they teach us to be human. New York: Columbia University Press.

Preece, Rod. 2005. Brute souls, happy beasts, and evolution: The historical status of animals. Vancouver: UBC Press.

Regan, Tom. 1985. The case for animal rights. In In defence of animals, ed. Peter Singer. Oxford: Basil Blackwell.

Secondhand Smoke. http://www.firstthings.com/blogs/secondhandsmoke/.

Smith, Wesley J. 2007. Four legs good, two legs bad: The antihuman values of 'animal rights'. The Human Life Review (Winter 2007): 7-15. Available on-line at http://www.humanlifereview.com/.... 
2009. A rat is a pig is a dog is a boy: The human cost of the animal rights movement. New York: Encounter.

Somerville, Margaret. 2010. We must protect humans' special status. Ottawa Citizen, January 22, 2010. Available on-line at http://www.christianity.ca/NetCommunity/Page.aspx? pid $=7150$.

spiked. http://www.spiked-online.com/.

Taylor, Angus. 2008. Electric sheep and the new argument from nature. In Animal subjects: An ethical reader in a posthuman world, ed. Jodey Castricano. Waterloo, Ont.: Wilfrid Laurier University Press.

Wilkins, John S. 2009. Species: A history of the idea. Berkeley: University of California Press. 